\title{
In Bogdaj as in Paradise, in Bogdaj
}

Srećko Petrović

Diocese of Šumadija, Aranđelovac

petrovic.srecko@gmail.com

ORCiD https://orcid.org/0000-0002-4916-6242

\author{
Over the Book \\ "Bogdaj" Bitola. [For the publisher Tomislav Karadžić; consultant Mirjana \\ Glišović; technical arrangement Dušan Solujić Sole]. Vraćevšnica [- Gornji \\ Milanovac: Grafoprint], 2019. 158 pp.
}

The charitable activity of Bishop Nicholai Velimirovich is little known. Although his work and service from the time before the First World War until the end of his life was associated with various charitable activities, his care for the needy and his engagement in the field of charity mostly escaped the attention of researchers, who focused their research firstly on his national work, dealing with the charitable dimensions of Velimirovich's activities arrogantly, more often only lightly or not at all. However, the charitable activity of Bishop Nicholai Velimirovich was one of his primary activities, expressed in different ways: through efforts to collect humanitarian aid during World War I, then through the establishment of various charitable funds and societies, in the interwar period through the establishment of the church charities, feeding houses for the poor, homes for children, homes for the elderly - in dioceses where he served as a bishop and administrator, 
or in monasteries in his vicinity, and in the period after World War II especially through care for displaced persons and refugees (among other things through work in international church organizations), care for surviving prisoners of war and detainees who could not return to their homes, and especially through care for poor believers in the new Yugoslavia expressed through his constant care to deliver humanitarian aid from the Western world to the unwilling in the homeland. The mentioned Bishop Nicholai's activities have not been sufficiently researched, and it would be very interesting if in the future they would be the subject of a more thorough study, i.e. if the charitable aspect of Bishop Nicholai's actions and ministry would be clarified.

In a small number of publications and studies in which certain attention is paid to the charitable activity of Bishop Nicholai, however, several articles stand out about the Children's Foster Home of St. Nicholas "Bogdaj," which operated under the direction of Nadežda - in monasticism Ana - Adžić in Bitola from 1935 to the beginning of World War II in the area, i.e. until the occupation in 1941. In addition to texts and materials from churchly periodicals, the first notable publication dedicated to "Bogdaj" through which the public had the opportunity to learn about the existence and activities of this charity was the diary of mother Ana Adžić, published among the articles for the biography of Bishop Nicholai in the $1^{\text {st }}$ volume of the Collected Works of Nicholai Velimirovich, i.e. in the $2^{\text {nd }}$ edition of the $1^{\text {st }}$ volume, printed in 2013.

An interesting publication about "Bogdaj", published in 2019, is coming from the Vraćevšnica monastery. This is the edition of the notebook of mother Ana Adžić, hegumenia of the Vraćevšnica monastery, who, as sister Nada, was invited by Bishop Nicholai in Bitola in 1935. She took over the management of the newly established Children's Foster Home of St. Nicholas - "Bogdaj." Namely, Sister Nada managed this institution until 1941, when after the outbreak of World War II and after the Bulgarian occupation, she had to leave Bitola. She lat- 
er continued her humanitarian work and mission in Kraljevo and Trstenik. The Vraćevšnica sisterhood copied this notebook in 1976 , thus preserving this valuable testimony from oblivion.

\section{У Богдају ка' у Рају, у Богдају}

Срећко Петровић

Епархија шумадијска, Аранђеловац

Над књигом

„Боїgаj” Битиољ. [За издавача Томислав Караџић; консултант Мирјана Глишовић; техничко уређење Душан Солујић Соле]. Враћевшница [- Горњи Милановац: Графопринт], 2019. 158 стр.

Харитативна делатност Епископа Николаја Велимировића мало је позната. Премда је његово деловање и служење још од времена пре 1. светскога рата па до краја његовог живота било скопчано са различитим харитативним активностима, његово старање о потребитима и његов ангажман на пољу добротворног рада углавном су измицали пажњи истраживача, који су опет своја истраживања усмеравали најпре на његов национални рад, бавећи се харитативним димензијама Велимировићевих активности више узгредно, чешће само овлаш или нимало. Међутим, харитативна делатност Епископа Николаја Велимировића била је једна од његових примарних делатности, изражавана на различите начине: кроз труд на прикупљању хуманитарне помоћи током 1. светског рата, потом кроз оснивање различитих добротворних фондова и друштава, у међуратном периоду кроз оснивање црквених добротвор- 
них установа, хранилишта за сиротињу, домова за децу, домова за старе - при дијецезама у којима је служио као архијереј и администратор, или при манастирима из његовог окружја, а у периоду после 2. светског рата нарочито кроз бригу за расељене и избегле (између осталога кроз рад у међународним црквеним организацијама), бригу за преживеле ратне заробљенике и логораше који се нису могли вратити својим домовима, и посебно кроз бригу за сиромашне вернике из нове Југославије - испољену кроз његово стално старање да се хуманитарна помоћ из западног света допреми невољнима у отаџбини. Поменуте активности Епископа Николаја нису истражене у довољној мери, и било би врло занимљиво уколико би у будућности оне биле предмет темељнијег проучавања, односно уколико би харитативни аспект деловања и служења Епископа Николаја био расветљен.

У невеликом броју публикација и студија у којима је одређена пажња посвећена харитативној делатности Владике Николаја, издваја се међутим неколико прилога о Дечијем хранилишту Светог Николе „Богдај“, које је под управом Надежде - у монаштву Ане - Аџић деловало у Битољу од 1935. године до почетка 2. светског рата на нашим просторима, односно до окупације 1941. године. Поред текстова и грађе из црквене периодике, ${ }^{1}$ прва запаженија публикација посвећена Богдају преко које је домаћа јавност имала

1 Уп. Нада С. Аџић (Игуманија мати Ана), „Дневник дечјег склоништа Св. Николе 'Богдај' у Битољу“, Светии Кнез Лазар: часойис за gуховни йрейороg, година VII, бр. 4 [28] (1999): 87-118; Надежда С. Аџић (касније Игуманија ман. Враћевшнице Ана), „Из дневника дечјег склоништа Св. Николе 'Богдај' у Битољу“, Светии Кнез Лазар: часойис за gуховни йрейороg, година VIII, бр. 1-2 [29-30] (200о): 103-128; Нада С. Аџић (Игуманија мати Ана), „Дневник дечјег хранилишта Св. Николе 'Богдај' у Битољу“, Светии Кнез Лазар: часойис за gуховни ӣрейороg, година VIII, бр. 3 [31] (20о0): 91-111; Надежда С. Аџић (Игуманија Ана), „Дневник дечјег хранилишта Св. Николе 'Богдај' у Битољу“, Свейи Кнез Лазар: часойис за gуховни ӣрейороg, година VIII, бр. 4 [32] (200о): 67-89; Нада С. Аџић (Игуманија Ана), „Дневник дечјег хранилишта Св. Николе 'Богдај' у Битољу“, Светии Кнез Лазар: часойис за gуховни ӣрейороg, година IX, бр. 1 и 2 [33 и 34] (2001): 65-10о. 
прилику да се упозна са постојањем и деловањем ове добротворне установе био је дневник мати Ане Аџић, објављен најпре узборнику Златиоустии йройовеgник васкрслоїа $X р и с \bar{u} a,{ }^{2}$ а потом међу прилозима за биографију Вл. Николаја у 1. тому Сабраних gела Николаја Велимировића, односно у 2. издању 1. тома, штампаном 2013. године. ${ }^{3}$

Овај дневник сачуван је љубављу враћевшничког сестринства, које се иначе постарало да публикује неколико издања о мати Ани, ${ }^{4}$ као и грађу за историју Богдаја, односно прилоге о сарадњи Епископа Николаја и сестре Наде / мати Ане, тј. о раду и деловање ове установе. ${ }^{5}$

2 Уп. Владимир Димитријевић и Горан Вељковић, прир., Злайоустии ирроиовеgник васкрслоїа Христиа: Светии Влаgика Николај у сећаюима савременика. [Книїа 1] (Крагујевац: Духовни луг, 2003).

3 Уп. Игуманија Ана Аџић, „Богдај. Дневник дечијег склоништа Св. Николе ‘Богдај’ у Битољу“, у Сабрана gела Ей. Николаја Велимировића, књига I, ур. Епископ Лаврентије (Трифуновић), свештеник Милисав Д. Протић и др. (Шабац: Глас Цркве, 2013), 811-89o. У успоменама Еп. Јована Велимировића, објављеним у истом тому Сабраних gела, помиње се „Богдај“, као и неке друге хуманитарне установе које је Николај Велимировић основао нешто касније као Епископ жички - ђачке кухиње и домови у Краљеву, Чачку, Горњем Милановцу и Трстенику (уп. [Еп. Јован Велимировић], „Сећања Еп. Јована Велимировића на Епископа Николаја“, у СД, I, 6о7698: 637-639, 650, итд.)

${ }^{4}$ На првом месту неколико књига Оливера Ђорђевића: Оливер Ђорђевић, Сретенн Аиић и юеїова йородица, Библиотека „Свети Ђорђе“ ([Горњи Милановац]: Манастир Враћевшница, 2001), 238 стр.; Сестринство манастира Враћевшница и Оливер Ђорђевић, прир., Оgабрани зайиси и

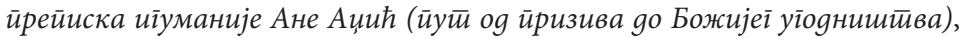
Библиотека „Свети Ђорђе“ / [Манастир Враћевшница, Горњи Милановац], књ. 2 (Горњи Милановац: Манастир Враћевшница, 2003), 361 стр.; Оливер Ђорђевић, Сретенн Ацић и юеі̄ова кћи иіууманија Ана, Библиотека „Свети Ђорђе“ ([Горњи Милановац]: Манастир Враћевшница, 2014), 470 стр.

Такође, овде би требало споменути и следећу монографију: Јевђа А. Јевђевић, прир., Белешке о матии Ани иіуманији манастичра Враћевшница: Из белешки и сећана сестиринстива манастиира Враћевшница (Враћевшница: Манастир Св. Георгија - Враћевшница, 2017), 96 стр.

${ }^{5}$ Уп. Ђорђевић, Срейен Аиић и юеіоова йородиия, 175-181; Сестринство манастира Враћевшница и Ђорђевић, прир., Оgабрани зайиси и йрейиска иіумманије Ане Ацић, 137-270; Ђорђевић, Срететен Ацић и юеіова кћи иіуманија Ана, 306-415, 444-448. 
Харитативна делатност Владике Николаја и историја Богдаја питања су која су начета и у неким студијама и монографијама: 6 пионирски подухвати на овом плану су истраживања проте Владимира Вукашиновића, ${ }^{7}$ монахиње Теодоре Васић, ${ }^{8}$ проте Бориса Милинковића, ${ }^{9}$ и посебно радови сабрани у зборнику посвећеном мати Ани, објављени у саиздавачком подухвату Факултета педагошких наука из Јагодине и Историјског архива „Средње Поморавље“,10 нарочито истраживања Љиљане Станков,,

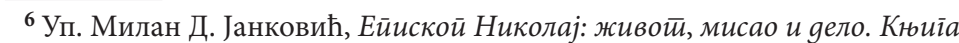
I (Београд [- Шабац]: Епархија шабачко-ваљевска, 2002), 456-468; Чарна Драговић [= Милинковић], „Група аутора: Златоусти проповедник васкрслог Христа: Свети Владика Николај у сећањима савременика, Духовни луг, Крагујевац 2003.“, Кулитура йолиса: часойис за неїоване gемокрайске йолитиччке кулитуре, година III, бр. 4-5 (2006): 791-795: 792-793; Владимир Димитријевић, Боі или мамон? (Православно учене о раgу, социјалној ирравgи и хришћанском солияаризму), 2. издање (Горњи Милановац: Лио, 2009), 43-45; Александар Стерјовски, Еgен век Црвен крсии во Бийола (Битола: Општинска организација на Црвен крст, 2012), 8-10; 14, 47, 59, 68-69.

${ }^{7}$ УП. Vladimir Vukašinović, "Die theologischen Quellen und Geschichte der karitativen Tätigkeit der Serbischen Orthodoxen Kirche im Laufe der Jahrhunderte," Philotheos: International Journal for Philosophy and Theology, Vol. 10 (2010): 337-359: 358-359, https://doi.org/10.5840/philotheos20101026.

8 Уп. Монахиња Теодора (Васић), „Игуманија мати Ана (Аџић) (190о1975)“, Гласник: службени листи Срӣске Православне Цркве, година XCVII, бр. 3 (март 2017): 93-99: 94-95.

9 Уп. Борис Милинковић, „Социјални карактер мисије Српске Православне Цркве у периоду 1918. - 2018.“, Социјална йолитиика / Social Policy: Часойис за йеорију и йраксу соиијалне йолитиике и социјалноі раgа, година 53, бр. 2-3 (2018): 115-131: 118-120, https://doi.org/10.22182/sp.232018.6.

10 Уп. Илијана Р. Чутура и Оливер Ђорђевић, ур., Иїуманија Ана (Аџић) - оличене йосвећеностии: зборник раяова йоводом 120 іолина оg рођена u 7 їоgина og ирримана монашкоі чина (Јагодина: Факултет педагошких наука Универзитета у Крагујевцу - Историјски архив „Средње Поморавље“, 2019), 171 стр.

11 Љиљана Станков, „Свети посао, са пуно љубави и душе - добротворни рад Надежде Аџић у Београду и Битољу“, у Иіумманија Ана (Аџић) -

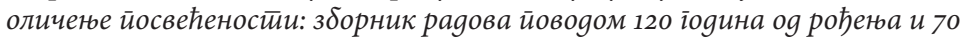
іоgина оg йримана монашкої чина, ур. Илијана Р. Чутура и Оливер Ђорђевић (Јагодина: Факултет педагошких наука Универзитета у Крагујевцу Историјски архив „Средње Поморавље“, 2019), 41-58: 52-56. 
Биљане Стојановић и Ане Миљковић Павловић, ${ }^{12}$ Весне Трифуновић, ${ }^{13}$ презвитера Ивице Камберовића, ${ }^{14}$ те Илијане Чутуре ${ }^{15}$ и Јелене Спасић. ${ }^{16}$

Оливер Ђорђевић је аутор који је овој теми дао посебан допринос, и то најпре кроз своје напоре у објављивању грађе, свој истраживачки рад, ${ }^{17}$ и такође кроз старање у вези са организовањем изложбе о мати Ани Аџић у Музеју рудничко-таковског краја у Горњем Милановцу 2019. године, скупа са Весном Ћурчић и Мирјаном Мокровчак-Глишовић. ${ }^{18}$

Поменути прилози драгоцени су јер су трагови деловања Епископа Николаја у не тако давној прошлости затирани, ${ }^{19}$

12 Биљана Стојановић и Ана Миљковић Павловић, „Слика детета у педагошком раду Надежде, потоње игуманије Ане Аџић“, у Иїуманија Ана (Ацић), ур. И. Р. Чутура и О. Ђорђевић, 81-93: 84-90.

13 Весна Трифуновић, „Ана Аџић: сведочење врлине љубави“, у Иіуманија Ана (Ацић), ур. И. Р. Чутура и О. Ђорђевић, 95-112: 99, 103.

14 Ивица Камберовић, „Благоделање сестре Надежде Аџић у Битољу и Трстенику“, у Иіуманија Ана (Аџић), ур. И. Р. Чутура и О. Ђорђевић, 113-122: 114-121.

15 Илијана Чутура, „О дневничким забелешкама Надежде Аџић (свеске из 'Богдаја')“, у Иїуманија Ана (Аиић), ур. И. Р. Чутура и О. Ђорђевић, 123-138.

16 Јелена Спасић, „Анализа мотива и стила писама Надежде Аџић“, у Иіуманија Ана (Ацић), ур. И. Р. Чутура и О. Ђорђевић, 139-154: 140-151.

17 Уп. Оливер Ђорђевић, „Дечје хранилиште ‘Богдај’ и Св. Владика Николај охридски и жички у писаној заоставштини Мати Ане (Аџић), игуманије манастира Враћевшница“, Гласник: службени лисй Срйске Православне Цркве, година LXXXVIII, бр. 5 (мај 2006): 149-158; уп. такође Оливер Ђорђевић, „Духовни сабори у Жичи и Св. Владика Николај у писаној заоставштини мати Ане (Аџић), игуманије манастира Враћевшнице“, у Наша йрошлосӣ. $7=$ Our Past: зборник pagoвa, ур. Драган Драшковић и Радомир Ристић (Краљево: Народни музеј - Историјски архив, 2006), 51-62: 53-55.

18 Уп. каталог ове изложбе, заправо врло информативну публикацију: Оливер Ђорђевић, Весна Ћурчић и Мирјана Мокровчак-Глишовић, Майи Ана Аиић (1900-1975): gуховно чеgо Влаgике Николаја Велимировића (Горњи Милановац: Музеј рудничко-таковског краја, 2019), 154 стр.

19 Тако из чланка Архиепископа охридског Јована сазнајемо да су поред црквених здања која су била везана за деловање Владике Николаја после 2. светског рата срушени и Богдај и Битољска богословија - уп. Митрополит велеско-повардарски Јован [Вранишковски], „Неки аспекти из пастирског рада Владике Николаја у Охриду и Битољу“, у Светии Влаgика 
можда и систематски, ${ }^{20}$ те у том смислу није никакво изненађење што је харитативна делатност Епископа Николаја мало позната. Стога је труд поменутих прегалаца значајан допринос потпунијем сагледавању живота и рада Владике Николаја Велимировића. Но труд о којем говоримо није окончан, јер из манастира Враћевшница стиже још једна интересантна публикација о Богдају, објављена 2019. године. ${ }^{21}$ У питању је издање свеске мати Ане Аџић, игуманије манастира Враћевшница, која је као сестра Нада на позив Еп. Николаја у Битољу 1935. године преузела управљање новооснованом Дечјим хранилиштем Св. Николе - Богдајем. ${ }^{22}$ Сестра Нада је наиме руководила овом установом до 1941. године, када је по избијању 2. светског рата и по бугарској окупацији морала напустити Битољ, да би по благослову Вл. Николаја свој хуманитарни рад и своју мисију наставила у Краљеву и Трстенику. Враћевшничко сестринство је ову свеску преписало 1976. године, сачувавши тако од заборава ово вредно сведочанство. ${ }^{23}$

Нажалост, књига није опремљена садржајем, а подаци о изворницима, грађи, објављеним документима итд. су сажети, каткада нејасни и непотпуни. Скромност и смире-

Николај Охрияски и Жички: йекст̄ови и свеgочења, симӣосион, ур. Епископ б. захумско-херцеговачки и приморски и помоћник и мјестобљуститељ жички Атанасије [Јевтић] (Краљево: Епархија Жичка - Свети манастир Жича, 2003), 462-466: 465-466.

20 Уп. Предраг Ристић, „Предлог за обнову изворне Капеле Св. Петра Цетињског“, Светии Кнез Лазар: часойис за gуховни ӣрейороg, година IX, бр. 3 [35] (2001): 59-86: 73.

21 „Боїgаj” Бийољ (Горњи Милановац: Манастир Враћевшница, 2019), 158 стр.

22 Оливер Ђорђевић, „Детињство Надежде Аџић, потоње високо преподобне мати Ане, игуманије манастира Враћевшница“, Корени: часойис за истиориоірафију и архивистичку, III (2005): 95-100: 98.

23 Према белешкама, благословом игуманије Стефаније и настојатељице манастира монахиње Марије, сестра Ирина преписала је ову свеску (уп. „Боїај” Битиољ, 154), довршивши препис у манастиру Враћевшница на дан Св. Симеона Богопримца, одн. 3/16. фебруара 1976. године (уп. „Боїgај” Битиоль, 158). 
ност трудбеника који су приредили ово издање читаоце остављају чак и без јасних и потпуних информација о ауторству, уређивачу и издавачу публикације. Као да се и данашњи приређивачи духовне литературе из скромности не потписују, уподобљујући се маниру сарадника Еп. Николаја и издавачких центара из међуратног периода који су му на одређени начин били блиски. Међутим, како би за критичко проучавање наслеђа Еп. Николаја било значајно да постоје и подаци о изворницима, као и описи рукописа, порекла грађе итд., у том погледу поменута неопремљеност с друге стране представља одређену препреку контекстуализацији и критичком сагледавању објављене грађе. С друге стране, поред поменутих мањкавости, објављивање

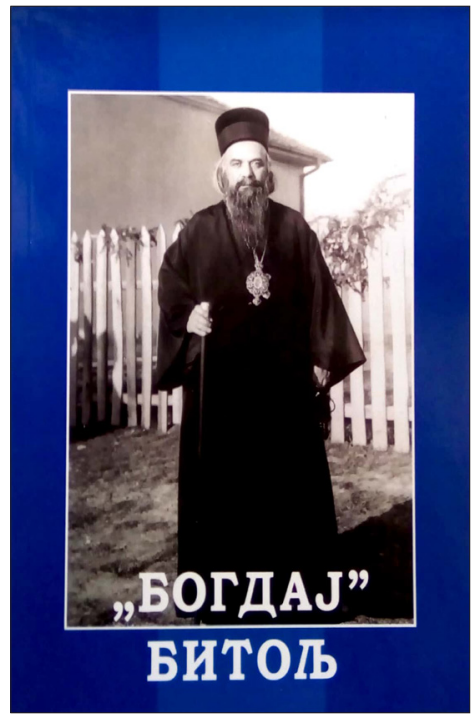
преписке Николаја Велимировића и сестре Наде Аџић свакако је драгоцени прилог познавању наше прошлости.

У овој публикацији објављени су бројни краћи прилози, и то следећим редом: Манастир Враћевшница (писмо игуманије Ксеније, о мати Ани и Еп. Николају, недатирано), стр. 5-10 [писмо садржи одређене анахронизме погрешно датирање оснивања Богдаја на 1933. уместо на 1935. годину, и смештање одвођења Еп. Николаја и Патр. Гаврила у Дахау током 1941. уместо 1944. године (сва је прилика да је мати Ксенија мислила на заточење двојице јерараха, које је започело током 1941. г.)]; „Богдај“ Битољ, стр. 11; Предговор је - извод из књиге „Речи о Свечовеку“ од Николаја Велимировића, стр. 13-14 (на крају, мати Ана прича како је Николај, сетивши се да у Речима о Свечовеку није споменуо Бога, исту књигу откупљивао и спаљивао - стр. 14 [међутим, у Речима о Свечовеку реч „Бог“ и изведенице срећу се око 200 пута, те није јасно 
на шта се заправо односи ова примедба]), затим се нижу писма Епископа охридско-битољског Николаја упућена сестри Нади Аџић и другим богдајским сестрама као и деци у Богдају, од 24. 12. 1935. године до 13/26. септембра 1936. године, стр. 15-38; следи писмо деце из Богдаја Еп. Николају, „Деда Владики“, од 17. септембра 1936. г., стр. 39; даље су ту песма снегу коју је у Богдају спевао Еп. Николај, а касније записао - 2. новембра 1936. г., стр. 4041; писма Еп. Николаја послата у Богдај, једно из Београда 13. новембра/2. децембра 1936. г. [сва је прилика лоше датирано - да ли само у штампи?], и друго недатирано, послато можда из Жиче, стр. 42-43; писмо Баба Захарије - Захе из Битоља, упућено Еп. Николају 18. новембра/1. децембра 1936. г., стр. 44-45; писма која су из Богдаја децембра 1936. г. Еп. Николају послали Ванђел Стојановић (стр. 46), Вељан Тавелић (стр. 47) и Драгољуб Јоксимовић (стр. 48). Потом долазе следећи прилози: писмо Еп. жичког Николаја деци у Богдају послато уочи Светог Николе 1936. г., стр. 49; честитка Еп. Николају за срећну нову 1937. годину коју су деца из Богдаја својеручно потписала, стр. 50-51; писма Еп. Николаја упућена деци и сестри Нади у Богдају, од 9/22. марта 1937. до 26. августа/8. септембра 1937. г., писана у Жичи, Краљеву, Београду (Патријаршији), Благовештењу Овчарском и опет Жичи, стр. 5261; цедуља од 3/16. септембра 1937. г. која је пратила поклон богдајске деце Еп. Николају (стр. 62), те писмо Еп. Николају које у име деце из Богдаја потписује Љубица Талевић (стр. 63). Следе писмо Еп. Николаја послато из Жиче деци и сестрама у Богдај 24. новембра/7. децембра 1937. г., те божићна честитка допуњена песмом о бадњаку коју Еп. Николај шаље у Богдај о Божићу 1938. године (стр. 64-68). Затим се нижу писма из преписке малих Богдајаца и Вл. Николаја (стр. 69-7о), опроштајно писмо богдајској деци које је Владика Николај написао приликом одласка из Битоља 1938. године („Ноћас док ви спавате, ја ћу бити на путу, далеко од Битоља. Али душа моја 
биће с вама. Све сам уредио и наредио што треба за вас...“ - стр. 71), писмо сестри Нади (стр. 72), писмо Деда Владици које из Богдаја о Светом Сави 1938. г. шаље сестра Нада (стр. 73-74), још писама из преписке малих Богдајаца, сестре Наде и Вл. Николаја из прве половине 1938. године (стр. 75-86), васкршњи поздрав Владике Николаја богдајским сестрама Нади, Софији, Марији, Марији, Милунки и бодгајској деци (стр. 87-89), те писма и упутства које он сестри Нади и Богдајцима даје као епископ жички током 1938. године (стр. 90-113), и одломци из писама и извештаја које је Еп. Николају слала сестра Нада (стр. 114-120). „Деда Владика“ фигурира као кључна личност Богдаја и у писмима сестре Наде другим личностима Јелени Лазаревић (стр. 121-124), и у њеним сећањима на рад по битољским кућама и служење битољској сиротињи (стр. 125-129). Он је желео да и богдајску децу укључи у ово служење, а старао се и о маргинализованим и сиротим женама. Сестра Нада бележи:

„Владика Николај је желео и деца да се уче милосрђу, не само да добијају милост, већ да је знају и делити и осећати за ближње. Преко дечијих руку сестре су такође делиле милосрђе из Богдаја појединим старицама, дечијим суседкама, које нису имале никога.

За децу су биле спремљене корпице у које би стао 1 хлебац, мала флашица ракије и тањир са парчетом већим сира (ако је пост пекмеза) и нека коцка шећера. Сваке недеље по ручку, на поласку своме дому, деца су радосно носила спремљено им да тиме обрадује своју бабу. Исто дете је и преко недеље обилазило па би доносило поруке од бабе ако јој шта треба, или зове сестру к себи. Ова веза је била велика утеха за ове самохране жене.

Сад ми је други свет. Сад ми је лако и живети и боловати и умрети, кад имам моје сестре које ме неће оставити. 
'Дедо Владико, тој нам направи ова добриња, тој го имамо како Св. Николу.“ (стр. 129; уп. такође стр. 153-154, за нешто другачију верзију овог записа).

Епископ Николај је отишавши из Охридско-битољске за Жичку епархију остао везан за дечија хранилишта: тако утиске из краљевачког хранилишта бележи у писму сестри Нади и Богдајцима датирано на 17. фебруар/2. март 1939. године (стр. 130-131: „И ми смо, хвала Богу, лепо прославили у нашем Хранилишту..."). Из одломака из писама сестре Наде који следе сазнајемо да је у Богдају основана Црква Светог Николе - „иза стаклене преграде у новој трпезарији“ (стр. 132). Деда Владика се премда удаљен и даље брине и богдајским сиротанима шаље кајмак, „слађи од шећера“, на чему му се из Богдаја захваљује Шенез Јакуб (стр. 133). У одломцима из писама сестре Наде који се надовезују на Јакубово писмо (стр. 134-137), сазнајемо да је било још оваквих пошиљака:

„Деца су сва добила меда, Ваш послатак, као благослов од Деда Владике. То је било право уживање гледати их како весело лижу мед дедин. Канда већу радост свет не зна. Њима дати нешто то је право задовољство.

Заиста су жељни свачега.“ (стр. 136).

На самом крају ове публикације штампан је текст пар дописница Вл. Николаја из 1939. године (стр. 138-139), још одломака из писама сестре Наде Еп. Николају (стр. 140), и Николајеви предлози сестри Нади о отварању женског интерната у Богдају - писмо које јој је послао 21. децембра 1939. године (стр. 141-142). По италијанском бомбардовању Битоља 1940. године, Владика Николај пише писмо сестри Нади, датирано на 5/23 новембар 1940. године (стр. 143).

Записник Сестринства при Цркви Св. Благовештења у Битољу, основаног 1939. године, датиран на 15/2. јануар 
1940. године, објављен на последњим странама ове публикације (стр. 145-154), потресно је сведочанство сестре Наде о сиромашним житељима Битоља, самохраним старицама и мајкама, сиротој и изгладнелој деци... Успомена на Владику Николаја и благодарност за његово деловање у Битољу сачувана је у овде објављеним речима Цветанке Колевић, записаним руком сестре Наде:

„Од како за вас знам, - вели - други ми је свет. Некако сам радосна и мирна. Богдај као благослов за сите (све) сиромасите и за деца сираци (сирочиће). Како мајка и татко да имамо, како сестре рођене вас имамо и ја и сите (сви). За овака добро од вас нам дојде. Сите се изразговарасмо са вас. И Деда Владика, Бог да га поживи, што учини добриња на сите сиромаси. Големо добро створи. Од кости Свето Миро да му тече!“ (стр. 153).

Занимљиво је приметити да љубав Владике Николаја није била усмерена искључиво према хришћанима, односно ексклузивно према члановима Цркве, или искључиво према Србима. У његовом раду у вези са Богдајем ово је лако уочљив детаљ. Примера ради, међу богдајским сирочићима поред српске и друге локалне деце православне вере, било је и турске, циганске и арнаутске деце исламске вероисповести (стр. 49, 51, 132, итд.). Деца из Богдаја су похађала веронауку, прослављала црквене празнике, учествовала у молитви и богослужењима, постила и причешћивала се, али су ишла и у посети битољској џамији (стр. 48).

Своје честитке и поздраве Николај шаље свој богдајској деци, и хришћанској и муслиманској (стр. 95). Владика Николај се залаже да у Богдај поред хришћанске долазе и муслиманска деца (стр. 105), брине шта ће јести муслиманска деца у Богдају - коју су родитељи давали у ово сиротиште јер су знали да се у њему није јело месо ни свињетина, већ риба из оближњих језера (стр. 103). Из књиге која је пред нама сазнајемо да се Влади- 
ка Николај није бринуо једино о деци исламске вере: сестра Нада извештава како је чабрицу кајмака - коју шаље Еп. Николај - предала „херцеговцу муслиманину ножару“ (стр. 140). ${ }^{24}$

Но смисао Богдаја превасходно је свакако била брига за децу. Брига и стрепња Вл. Николаја за мале Богдајце је очинска. Сведочанства из писама сачуваних у свесци мати Ане упечатљива су и жива. Однос Владике Николаја према деци животан је и нешаблонски. Он прилагођава и свој речник - поздравља их у стиховима, пише им песмице. ${ }^{25}$ Бодри их и крепи, подстиче на љубав. На дан Свете Катарине, 24. новембра/7. децембра 1937. године из Жиче Владика Николај пише Богдајцима:

„Певате ли?

Радујете ли се?

Волите ли се?

Молите ли се?“" (стр. 65).

Јачајући везу са дечијим срцима, Вл. Николај себе у богдајским писмима себе често потписује као „Деда Владика“, а Патријарха Варнаву Росића назива „Деда Патрика“

24 О односу Еп. Николаја према иновернима у Богдају, уп. и Камберовић, „Благоделање сестре Надежде Аџић у Битољу и Трстенику“, 119-121.

25 Сачувано је више оваквих песама. У издању које је пред нама неколико њих (уп. „Боїgaj” Битиољ, 15, 40-41, 55, 66-67). Песма сачувана у писму послатом деци у Богдају о Благовестима 1937. године из манастира Жича („Боїgај” Бит̄ољ, 55), којом се Владика Николај захваљује малим Богдајцима на послатом букету цвећа („Помози вам Бог децо! / Примио сам шарено цвеће, / Из 'Богдаја' ка' из Раја, / Примио сам све букете, / Рука ваша што исплете, / И прстенке, љубичице, / И метвице и душице..."), и потом разговарајући са букетом извињава што није долазио и обећава скорашњи сусрет („Чувши шта ми цвеће збори, / Од стида ми лице гори, / Добро, добро, цвеће мило / Растанка је доста било! / ... Па кад стара врата шкрипну, / Сва ће деца да узвикну; / 'Ево деде, устаните, / И у сред се поставите, / С нашим дедом да стојимо, / Милог Бога да славимо!“), објављена је раније у Ђорђевић, „Дечје хранилиште ‘Богдај’ и Св. Владика Николај“, 152-153. 


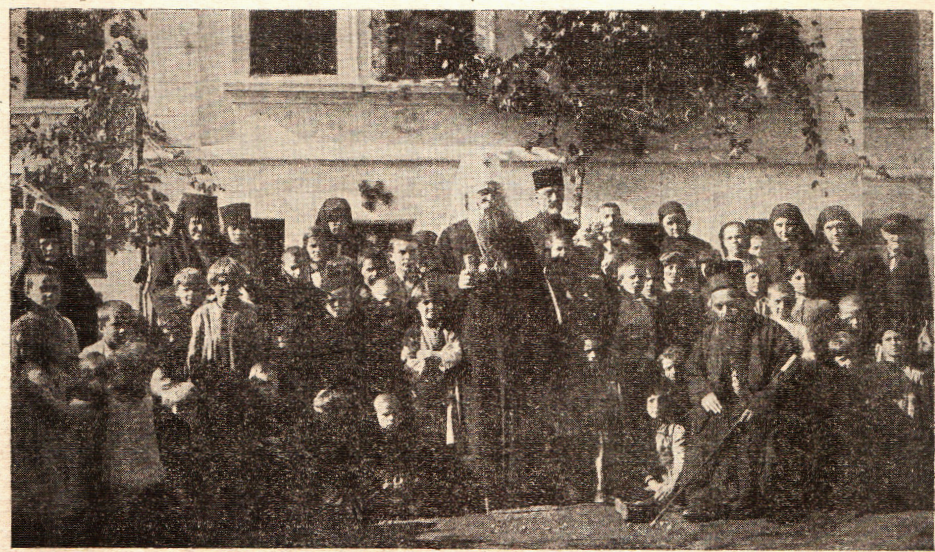

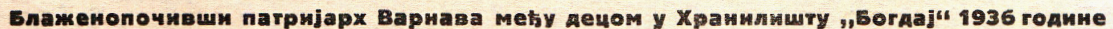
Прилоге слати на адресу Хранилишта: Бнтољ, Серајевска улица 6рој 43.

Fig. 1. Patriarch Varnava Rosić and Bishop Nicholai Velimirovich visit the Bogdaj orphanage in 1936 (source: The Missionary, Vol. XX, No. 4-5 (April-May 1940): 45)

Сл. 1. Патријарх Варнава Росић и Епископ Николај Велимировић у посети сиротишту „Богдај“ 1936. године (извор: Мисионар, год. ХХ, бр. 4-5

(април-мај 1940): 45)

(стр. 42). Деца Епископа Николаја опет једино тако и ословљавају - за њих је он једноставно „Деда Владика“. У Богдају - ка’ у Рају.

Сачувана је Химна Богдаја, коју је написао Епископ Николај. Како бележи мати Ана, Владика Николај је ову песму написао богдајској деци и прочитао им је 24. децембра 1935. године: 
„Ми смо мали Битољчани

Малишани, сиротани

Кућа нам је баш на крају

У Богдају ка' у Рају,

У Богдају.

Бог нам шаље доста хлеба

И остало што нам треба,

Па ако смо и на крају

Ми живимо ка' у Рају

У Богдају.

Богати смо братском слогом, Радосни смо благим Богом, Захвални смо што нам дају, Играмо се ка' у Рају у Богдају.

Учимо се добри бити

И свом роду користити

Тако наши дани трају

У Богдају ка' у Рају

у Богдају.“ (стр. 15). ${ }^{26}$

Будући да је било отворено за све, богдајско сиротиште било је својеврсна „мултинационална, мултиверска и свечовечанска колонија“.27 Владика Николај се тиме поносио и често истицао Богдај као пример, бележе биографи Епископа Николаја.

26 Ова химна објављена је у часопису Мисионар 1940. године: уп. „Химна Дечјег хранилишта Св. Николе ‘Богдај' у Битољу“, Мисионар: оріан

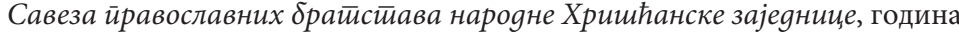
$\mathrm{XX}, 6$ p. 4-5 (април-мај 1940): 44; за краћу и нешто другачију верзију ове химне, уп. Љубомир Ранковић, Свет̄и Влаgика Николај: животи и gело (Шабац: Глас Цркве, 2013), 100.

27 Ранковић, Светии Влаgика Николај, 99. 


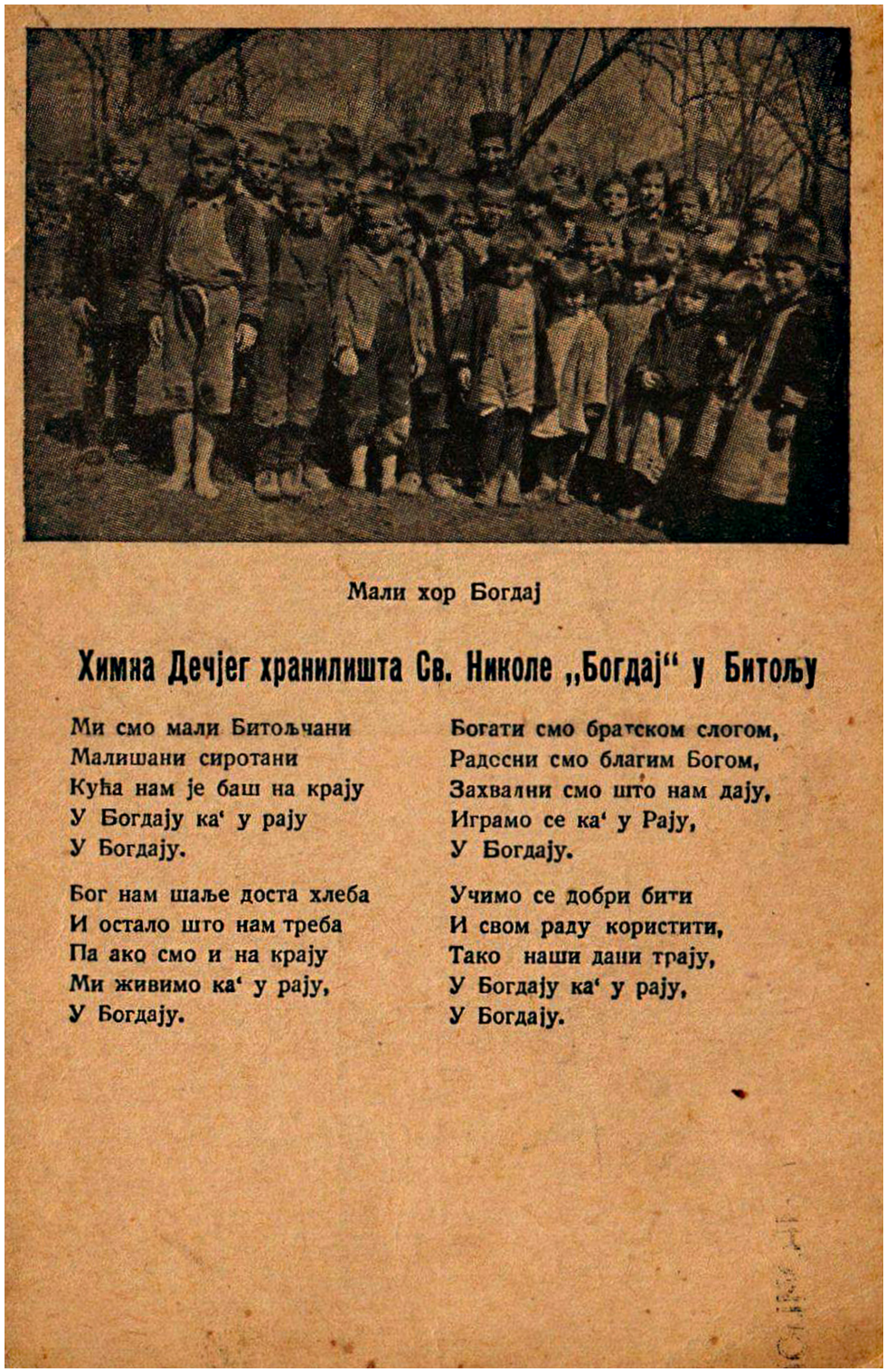

Fig. 2. Hymn of Bogdaj, a leaflet for collecting aid for Bogdaj, cca. 1940 Сл. 2. Химна Богдаја, петак за прикупљање помоћи за Богдај, око 1940. г. 
Епископ шабачки Јован Велимировић, синовац Епископа Николаја, се присећа:

\begin{abstract}
„Богдај је био Владици најмилији. То је најосетљивији дамар Владичин. Чинило нам се, гледајући све то, да је Владика живео за Богдај. Није било дана да Владика није посетио Богдај и провео извесно време са децом. Деца су му се пентрала по коленима, увлачила у мантије, скакала око њега, а он се само смејао и све деци дозвољавао. О Богдају је певао, писао, говорио. Ако је неко хтео да га развесели и орасположи, нека само почне разговор о Богдају.“28
\end{abstract}

Са Богдајем су, поред Епископа Николаја и сестре Наде / мати Ане Аџић биле повезане и друге знамените личности наше прошлости - и црквене и друштвене. Примера ради, у Богдају је примила монашки постриг и живела монахиња Стефанида (Стевка) Ђурчевић (1887-1945). ${ }^{29}$ Јован Максимович (1896-1966), Епископ шангајски и касније Архиепископ Сан Франциска, према тврдњама које се срећу у његовим биографијама, често је посећивао Богдај. ${ }^{30}$ Постоје неке тврдње да су штићеници Богдаја као деца били Лазар Колишевски (1914-200о) и његова рођена сестра, и друге личности. Међутим, историја Богдаја тек би требало да се истражи.

\footnotetext{
${ }^{28}$ Наведено према Велимировић, „Сећања Еп. Јована Велимировића на Епископа Николаја“, СД, I, 639; уп. и Ранковић, Свеш̄и Влаgика Николај, 99-100.

29 Уп. Јеромонах Др. Амфилохије (Радовић), „Исихазам као освајање унутрашњих простора“, Теолошки ӣоїлеgи: версконаучни часойис, година IX, бр. 3 (1976): 145-152: 150; уп. такође Лазар Љубић, „Свете жене Српске Цркве“, Православље: новине Срӣске Пайријариије, година LII, бр. 1242 (15. децембар 2018): 41-42: 42.

30 Уп. Пётр Перекрестов (сост.), Владька Иоанн - святитель Русского Зарубежья, Серия «Жития святых», 4-е изд. (Москва: Сретенский монастырь, 2014), 4о. Уп. такође Бернард Ле Каро, Светии Јован Шаніајски чуgойвораи, йослеgюих времена, књигу приредио Петар Перекрјостов, са руског превела Марина Тодић, редактура превода Ксенија Кончаревић, Библиотека „Образ светачки“, књ. 124 (Београд: Православна мисионарска школа при Храму Светог Александра Невског, 2013), 35.
} 
Богдајске везе у животу и раду Епископа Николаја биле су снажне и постојане, и нису прекинуте његовим премештајем на катедру Епархије жичке. Преписка објављена у публикацији „Боїgај” Битиољ показује како је Николај неговао ове везе. Сачувани су и други трагови тих веза: у периодици из окружја Владике Николаја, Богдај је присутан као актуелна тема, можда и као модел којем би требало подражавати - у контексту проширене харитативне делатности Еп. Николаја као владике жичког. ${ }^{31}$ И после 2. светског рата, као избеглица у западном свету, Епископ Николај ће наставити оно што је започео у Богдају, између осталога и кроз настављање сарадње са мати Аном - „мати Богдајком“, како је назива ${ }^{32}$ остваривано кроз управљање добротворним фондовима, посредовање у разним приликама, логистичку подршку итд. ${ }^{33}$

Књига „Боїgаj” Бит̄ољ вредна је и због тога што се појављује као сведочанство о позитивним аспектима живота и рада Епископа Николаја. И то у времену када је један процес преобликовања његовог лика и дела такорећи довршен, и када је он малтене коначно и неопозиво проглашен ретроград-

\footnotetext{
31 Уп. нпр. текст о оснивању сиротишта у Чачку по угледу на Богдај: „У Чачку је основано Дечије хранилиште“, Мисионар: орїан Савеза

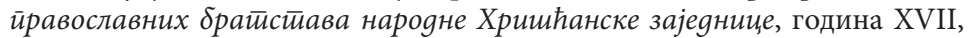
бр. 1 (јануар 1937): 24; писмо богдајске деце - „Апели“, Мисионар: оріан

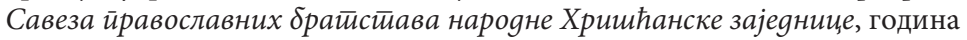
XX, бр. 1 (јануар 1940): [33]; „Благодарност добротворима Дечјег хранилишта Св. Николе 'Богдај' у Битољу“, Мисионар: оріан Савеза ӣравославних

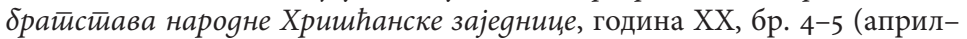
мај 1940): 44-45; „Благодарност Дечјег хранилишта у Битољу“, Мисионар: орїан Савеза йравославних брайсйава народне Хришћанске зајеgнице, година XX, бр. 12 (децембар 1940): 31-32, итд.

32 Уп. његово писмо о. Димитрију Најдановићу од 13. фебруара 1954. године, објављено у Жељко 3. Јелић, прир., Нейознатиа йисма Свеӣов Николаја Срйскоі̄ (Београд: Завод за унапређивање образовања и васпитања Хришћанска мисао, 2009), 64-65: 64.

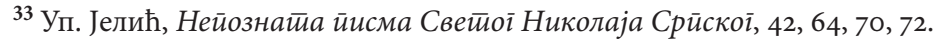


ном и мрачном фигуром, ускогрудим националистом, чак и шовинистом, и то не само у појединим програмским текстовима већ и у академским истраживањима. Поздрављајући труд враћевшничког сестринства и анонимних приређивача да се ова публикација појави, надамо се да ће Богдај и харитативно деловање Владике Николаја уопште привући и пажњу истраживача.

\section{Библиографија:}

„Апели“. Мисионар: оріан Савеза йравославних брайсйава народне Хришћанске зајеgнице, година ХХ, бр. 1 (јануар 1940): [33]. „Благодарност Дечјег хранилишта у Битољу“. Мисионар: оріан Савеза иравославних брайстиава нарояне Хришћанске зајеgниие, година ХХ, бр. 12 (децембар 1940): 31-32.

„Благодарност добротворима Дечјег хранилишта Св. Николе 'Богдај' у

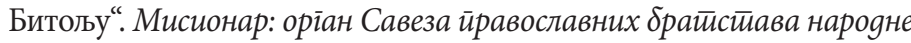
Хришћанске зајеgнице, година ХХ, бр. 4-5 (април-мај 1940): 44-45. „Боїgаj” Бит̄оль. Горњи Милановац: Манастир Враћевшница, 2019. „У Чачку је основано Дечије хранилиште“. Мисионар: оріан Савеза

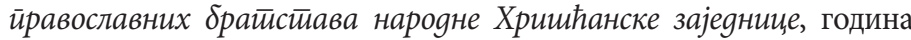
XVII, бр. 1 (јануар 1937): 24.

„Химна Дечјег хранилишта Св. Николе ‘Богдај’ у Битољу“. Мисионар: оріан Савеза ирравоставних брайсйава нарояне Хришћанске зајеgнице, година XX, бр. 4-5 (април-мај 1940): 44.

Vukašinović, Vladimir. "Die theologischen Quellen und Geschichte der karitativen Tätigkeit der Serbischen Orthodoxen Kirche im Laufe der Jahrhunderte" Philotheos: International Journal for Philosophy and Theology, Vol. 10 (2010): 337-359. https://doi.org/10.5840/philotheos20101026.

Аџић, Игуманија Ана. „Богдај. Дневник дечијег склоништа Св. Николе ‘Богдај' у Битољу“. У Сабрана gела Еӣ. Николаја Велимировића, књига I, ур. Епископ Лаврентије (Трифуновић), свештеник Милисав Д. Протић и др., 811-89о. Шабац: Глас Цркве, 2013.

Аџић, Нада С. (Игуманија Ана). „Дневник дечјег хранилишта Св. Николе 'Богдај' у Битољу“. Свейи Кнез Лазар: часойис за gуховни üpeūopog, година IX, бр. 1 и 2 [33 и 34] (2001): 65-10о. 
Аџић, Нада С. (Игуманија мати Ана), „Дневник дечјег хранилишта Св. Николе 'Богдај' у Битољу“, Светии Кнез Лазар: часойис за gуховни üрейороg, година VIII, 6р. 3 [31] (200о): 91-111.

Аџић, Нада С. (Игуманија мати Ана). „Дневник дечјег склоништа Св. Николе 'Богдај' у Битољу“. Свеиии Кнез Лазар: часойис за gуховни йрейороg, година VII, бр. 4 [28] (1999): 87-118.

Аџић, Надежда С. (Игуманија Ана). „Дневник дечјег хранилишта Св. Николе 'Богдај' у Битољу“. Свеиии Кнез Лазар: часойис за gуховни üрейороg, година VIII, 6р. 4 [32] (2000): 67-89.

Аџић, Надежда С. (касније Игуманија ман. Враћевшнице Ана). „Из дневника дечјег склоништа Св. Николе 'Богдај' у Битољу“. Свеиии Кнез Лазар: часоиичс за ууховни йрейороg, година VIII, бр. 1-2 [29-30] (2000): 103-128.

Васић, Монахиња Теодора. „Игуманија мати Ана (Аџић) (1900-1975)“. Гласник: службени лисй Срйске Православне Цркве, година XCVII, бр. 3 (март 2017): 93-99.

Велимировић, Еп. Јован. „Сећања Еп. Јована Велимировића на Епископа Николаја. У Сабрана gела Еӣ. Николаја Велимировића, књига I, ур. Епископ Лаврентије (Трифуновић), свештеник Милисав Д. Протић и др. (Шабац: Глас Цркве, 2013), 607-698. Шабац: Глас Цркве, 2013.

Велимировић, Николај. Сабрана gела Ей. Николаја Велимировића, књига I. Ур. Епископ Лаврентије (Трифуновић), свештеник Милисав Д. Протић и др. Шабац: Глас Цркве, 2013.

Велимировић, Николај. Сабрана gела, I-XIII. Шабац: Манастир Светог Николаја Соко, 2016.

Вранишковски, Митрополит велеско-повардарски Јован. „Неки аспекти из пастирског рада Владике Николаја у Охриду и Битољу“. У Светии Влаgика Николај Охрияски и Жички: иекксйови и свеgоченьа, симӣосион, ур. Епископ б. захумско-херцеговачки и приморски и помоћник и мјестобљуститељ жички Атанасије [Јевтић], 462-466. Краљево: Епархија Жичка - Свети манастир Жича, 2003.

Димитријевић, Владимир, и Горан Вељковић, прир. Злайоусӣи йройовеgникваскрстоїа Хрисӣа: Светии Влаgика Николај у сећаюима савременика. [Книїа 1]. Крагујевац: Духовни луг, 2003.

Димитријевић, Владимир. Бої или мамон? (Православно учете о раgу, социјалној ирравgи и хришћанском солияаризму), 2. издање. Горњи Милановац: Лио, 2009. 
Драговић, Чарна. „Група аутора: Златоусти проповедник васкрслог Христа: Свети Владика Николај у сећањима савременика, Духовни луг, Крагујевац 2003." Кулитура йолиса: часойис за неїоваюе gемократиске йолитичике кулитуре, година III, бр. 4-5 (2006): 791-795.

Ђорђевић, Оливер, Весна Ћурчић и Мирјана Мокровчак-Глишовић. Майи Ана Аиић (1900-1975): gуховно чеgо Влаяике Николаја Велимировића. Горњи Милановац: Музеј рудничко-таковског краја, 2019.

Ђорђевић, Оливер. „Детињство Надежде Аџић, потоње високо преподобне мати Ане, игуманије манастира Враћевшница“. Корени: часойис за истиориоірафију и архивистиику, III (2005): 95-10о.

Ђорђевић, Оливер. „Детињство Надежде Аџић, потоње високо преподобне мати Ане, игуманије манастира Враћевшница“. Корени: часойис за истиориоірабију и архивистиику, III (2005): 95-10о.

Ђорђевић, Оливер. „Дечје хранилиште ‘Богдај’ и Св. Владика Николај охридски и жички у писаној заоставштини Мати Ане (Аџић), игуманије манастира Враћевшница“. Гласник: службени листи Срйске Православне Цркве, година LXXXVIII, 6р. 5 (мај 2006): 149-158.

Ђорђевић, Оливер. „Духовни сабори у Жичи и Св. Владика Николај у писаној заоставштини мати Ане (Аџић), игуманије манастира

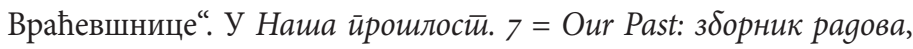
ур. Драган Драшковић и Радомир Ристић, 51-62. Краљево: Народни музеј - Историјски архив, 2006.

Ђорђевић, Оливер. Сретенен Аиић и неіова кћи иіумманија Ана, Библиотека „Свети Ђорђе“. [Горњи Милановац]: Манастир Враћевшница, 2014.

Ђорђевић, Оливер. Сретеен Аиић и юеі̄ова йородица, Библиотека „Свети Ђорђе“. [Горњи Милановац]: Манастир Враћевшница, 2001.

Јанковић, Милан Д. Ейиской Николај: живой, мисао и gело. Кюиїа I. Београд [- Шабац]: Епархија шабачко-ваљевска, 2002.

Јевђевић, Јевђа А., прир. Белешке о матии Ани иіуманији манастиира Враћевшниц: Из белешки и сећана сестиринсива манасиира Враћевшница. Враћевшница: Манастир Св. Георгија - Враћевшница, 2017.

Јелић, Жељко З., прир. Нейознайа йисма Свеӣой Николаја Срйскої. Београд: Завод за унапређивање образовања и васпитања - Хришћанска мисао, 2009. 
Камберовић, Ивица. „Благоделање сестре Надежде Аџић у Битољу и Трстенику“. У Иіуманија Ана (Аџић) - оличене йосвећеносии: зборник раяова йоводом 120 іолина оg рођења и 70 іолина оg ирримана монашкоі чина, ур. Илијана Р. Чутура и Оливер Ђорђевић, 113-122. Јагодина: Факултет педагошких наука Универзитета у Крагујевцу Историјски архив „Средње Поморавље“, 2019.

Ле Каро, Бернард. Светии Јован Шаніајски - чуgойвораи, йослеgних времена. Књигу приредио Петар Перекрјостов, са руског превела Марина Тодић, редактура превода Ксенија Кончаревић. Библиотека „Образ светачки“, књ. 124. Београд: Православна мисионарска школа при Храму Светог Александра Невског, 2013.

Љубић, Лазар. „Свете жене Српске Цркве“. Православље: новине Срйске Пайријариије, година LII, бр. 1242 (15. децембар 2018): 41-42.

Милинковић, Борис. „Социјални карактер мисије Српске Православне Цркве у периоду 1918. - 2018.“ Социјална йолитиика / Social Policy: Часойис за йеорију и йраксу соиијалне йолитиике и соиијалноі раgа, година 53, бр. 2-3 (2018): 115-131. https://doi.org/10.22182/sp.232018.6.

Перекрестов, Пётр, сост. Владыка Иоанн - святитель Русского Зарубежья, Серия «Жития святых», 4-е изд. Москва: Сретенский монастырь, 2014. Радовић, Јеромонах Др. Амфилохије. „Исихазам као освајање унутрашњих простора“. Теолошки ӣоїлеgи: версконаучни часойис, година IX, бp. 3 (1976): 145-152.

Ранковић, Љубомир. Светии Влаgика Николај: животи и gело. Шабац: Глас Цркве, 2013.

Ристић, Предраг. „Предлог за обнову изворне Капеле Св. Петра Цетињског“. Светии Кнез Лазар: часоӣuс за ууховни йрейороg, година IX, 6p. 3 [35] (2001): 59-86.

Сестринство манастира Враћевшница и Оливер Ђорђевић, прир. Оgабрани зайиси и иррейиска иіуманије Ане Аиић (йуй оg йризива gо Божијеі уїоднишешва), Библиотека „Свети Ђорђе“ / [Манастир Враћевшница, Горњи Милановац], књ. 2. Горњи Милановац: Манастир Враћевшница, 2003.

Спасић, Јелена. „Анализа мотива и стила писама Надежде Аџић“. У Иіуманија Ана (Аиић) - оличење йосвећеносиии: зборник раgова йоводом 120 іолина оg рођеньа и 70 іодина оg иримања монашкоі чина, ур. Илијана Р. Чутура и Оливер Ђорђевић, 139-154. Јагодина: 
Факултет педагошких наука Универзитета у Крагујевцу - Историјски архив „Средње Поморавље“, 2019.

Станков, Љиљана. „Свети посао, са пуно љубави и душе - добротворни рад Надежде Аџић у Београду и Битољу“. У Иїмманија Ана (Аџић) оличене йосвећеностии: зборник раgова йовоgом 120 їодина оg рођетьа и 70 ĭoguна og ирримана монашкоі чина, ур. Илијана Р. Чутура и Оливер Ђорђевић, 41-58. Јагодина: Факултет педагошких наука Универзитета у Крагујевцу - Историјски архив „Средње Поморавље“, 2019.

Стерјовски, Александар. Еgен век Црвен крсти во Бийола. Битола: Општинска организација на Црвен крст, 2012.

Стојановић, Биљана, и Ана Миљковић Павловић. „Слика детета у педагошком раду Надежде, потоње игуманије Ане Аџић“. У Иїуманија Ана (Аиић) - оличетье йосвећеностии: зборник раgова йоводом 120 іоgина оg рођењь и то іоgина оg иримана монашкоі чина, ур. Илијана Р. Чутура и Оливер Ђорђевић, 81-93. Јагодина: Факултет педагошких наука Универзитета у Крагујевцу - Историјски архив „Средње Поморавље“, 2019.

Трифуновић, Весна. „Ана Аџић: сведочење врлине љубави“.У Иїуманија Ана (Аиић) - оличене йосвећеностии: зборник раяова йоводом 120 іоgина оg рођењ а и $7 о$ іолина оg иримана монашкоі чина, ур. Илијана Р. Чутура и Оливер Ђорђевић, 95-112. Јагодина: Факултет педагошких наука Универзитета у Крагујевцу - Историјски архив „Средње Поморавље“, 2019.

Чутура, Илијана Р., и Оливер Ђорђевић, ур. Иіуманија Ана (Аиић) оличенье йосвећеностии: зборникраяова йоводом 120 іо оина оg рођеньа и 70 їоgина og ирримаґа монашкої чина. Јагодина: Факултет педагошких наука Универзитета у Крагујевцу - Историјски архив „Средње Поморавље“, 2019.

Чутура, Илијана. „О дневничким забелешкама Надежде Аџић (свеске из 'Богдаја')“. У Иіумманија Ана (Аиић) - оличене йосвећеностии:


монашкоі чина, ур. Илијана Р. Чутура и Оливер Ђорђевић, 123-138. Јагодина: Факултет педагошких наука Универзитета у Крагујевцу Историјски архив „Средње Поморавље“, 2019. 